\title{
PENGARUH MODEL PEMBELAJARAN LEARNING CYCLE (SIKLUS BELAJAR) 5 FASE TERHADAP KETERAMPILAN SOSIAL SISWA PADA MATA PELAJARAN IPS SISWA KELAS VII SMP NEGERI 2 SERIRIT
}

\author{
Made Juni Astuti ${ }^{1}$, Iyus Akhmad Haris ${ }^{2}$, Lulup Endah Tripalupi ${ }^{3}$ \\ Program Studi Pendidikan Ekonomi \\ Universitas Pendidikan Ganesha \\ Singaraja, Indonesia \\ e-mail: juniastuti629@gmail.com ${ }^{1}$, ivusharis55@gmail.com², \\ lulup tripalupi@yahoo.com ${ }^{3}$
}

\begin{abstract}
Abstrak
Penelitian ini bertujuan untuk mengetahui pengaruh keterampilan sosial siswa yang menggunakan pembelajaran model learning cycle 5 fase dan pembelajaran konvensional dilihat dari keterampilan untuk hidup dan bekerjasama, keterampilan untuk mengontrol diri dan orang lain, keterampilan berinteraksi, keterampilan bertukar pikiran dan pengalaman. Penelitian ini merupakan penelitian eksperimen semu dan rancangan atau desain kelompok kontrol hanya pos tes saja. Subjek penelitian adalah siswa kelas VII C dan siswa kelas VII D. Objek dalam penelitian ini adalah keterampilan sosial siswa dan model pembelajaran learning cycle 5 fase. Data dikumpulkan dengan menggunakan lembar observasi, data dianalisis menggunakan analisi uji-t. Hasil penelitian menunjukkan bahwa terdapat pengaruh keterampilan sosial siswa yang menggunakan pembelajaran model learning cycle 5 fase dan pembelajaran model konvensional dilihat dari keterampilan untuk hidup dan bekerjasama dengan nilai signifikan $0,000<0,05$, keterampilan untuk mengontrol diri dan orang lain dengan nilai signifikan $0,003<0,05$, keterampilan berinteraksi dengan nilai signifikan $0,005<0,05$, keterampilan bertukar pikiran dan pengalaman dengan nilai signifikan $0,000<0,05$.
\end{abstract}

Kata kunci : model pembelajaran, learning cycle, keterampilan sosial, pembelajaran IPS

\begin{abstract}
This study was determines the difference of student social skills who using learning cycle 5 phases model and conventional learning seen from the skills to live and cooperate, skills to control themselves and others, interact skills, exchange ideas and experience skills. This research was a quasi-experimental and the design of a control group was only a posttes. The subjects in this study were students of VII C class and students of VII D class. The object in this study was the social skills of the students and the 5 phases learning cycle model. The data were collected using an observation sheet, the data analyzed by using t-test analysis. The results showed that, there were some differences between social skills of students who using the learning cycle model 5 phases and conventional are seen from the skills and work together with a significant value of $0,000<0,05$, skills to control themselves and others with a significant value of $0,003<0,05$, interacting skills with a significant value of 0,005 $<0,05$, the skill of exchanging ideas and experience with a significant value of 0,000 $<0,05$.
\end{abstract}

Keyword : learning model, learning cycle, social skill, social science learning 


\section{PENDAHULUAN}

Penerapan model pembelajaran menjadi salah satu faktor utama dalam proses pembelajaran karena ketika menerapkan model pembelajaran yang sesuai dengan mata pelajaran dan kondisi siswa maka proses pembelajaran dan hasil belajarnya pun akan sesuai dengan yang diharapkan. Banyak model pembelajaran yang dapat diterapkan dalam proses pembelajaran. Model pembelajaran merupakan gambaran upaya guru untuk membuat situasi dalam kegiatan pembelajaran sehingga mendorong siswa untuk belajar. Menurut Sobandi (2008) model pembelajaran adalah suatu desain yang menggambarkan proses rincian dan penciptaan situasi lingkungan yang memungkinkan siswa berinteraksi sehingga terjadi perubahan atau perkembangan pada diri siswa. Suatu model pembelajaran dapat memberikan beberapa manfaat, pertama memberikan pedoman bagi guru dan siswa bagaimana proses mencapai tujuan pembelajaran. Kedua, membantu dalam pengembangan kurikulum bagi kelas dan mata pelajaran lain. Ketiga, membantu dalam memilih media dan sumber. Keempat, membantu meningkatkan efektifitas pembelajaran. Keberhasilan pencapaian tujuan pendidikan di sekolah bergantung pada proses belajar yang dialami siswa berbagai metode, model, dan strategi yang dilakukan oleh guru. Guru merupakan salah satu komponen penting dalam pendidikan. Mutu pendidikan dapat meningkat bila guru dapat memberikan pembelajaran yang berarti pada siswa.

Salah satu model yang dapat di terapkan oleh guru adalah model pembelajaran learning cycle. Menurut Suprijono (2016) model learning cycle (siklus belajar) adalah suatu model pembelajaran yang berpusat pada pebelajar (student centered). Model learning cycle (siklus belajar) merupakan rangkaian tahap-tahap kegiatan yang diorganisasikan sedemikian rupa sehingga pebelajar dapat menguasai kompetensikompetensi yang harus dicapai dalam pembelajaran dengan cara berperan aktif. Sedangkan Menurut Wena (2009) model 
pembelajaran siklus belajar merupakan salah satu model pembelajaran dengan pendekatan kontruktivis. Teori kontruktivis menyatakan bahwa siswa harus menemukan sendiri dan menstransformasikan informasi kompleks, mengecek informasi baru dengan aturanaturan lama dan merevisinya apabila aturan-aturan itu tidak lagi sesuai (Trianto

2010). Menurut Suastra (2017) model

pembelajaran learning cycle 5E merupakan perwujudan dari filosofi kontruktisme tentang belajar dan

belajar) terdiri dari lima fase menurut Sadia (2014) adalah engagement, exploration, explaination, elaboration, dan evaluation. Pada tahap engagement, guru berusaha membangkitkan minat dan keingintahuan siswa tentang materi yang akan dipelajari, kegiatan ini dapat dilakukan guru dengan mengaitkan materi pembelajaran pada kehidupan sehari-hari. Fase ini dapat membantu siswa dalam memahami atau mengidentifikasi masalah-masalah yang akan mereka hadapi. Tahap exploration peserta didik diberi kegiatan yang dapat melibatkan keaktifannya untuk menguji prediksi dan hipotesis melalui alternatif yang diambil, mencatat hasil pengamatan dan mendiskusikan dengan peserta didik yang lain. Dengan demikian, peserta didik memiliki kesempatan bekerja sama dengan kelompok-kelompok kecil tanpa pengajaran langsung dari guru. Fase ini adalah untuk menyediakan pemerolehan pengalaman nyata bagi siswa dimana mengajak siswa secara langsung. Tahap explanation guru memberikan kesempatan kepada siswa untuk melakukan diskusi kelompok untuk menjelaskan dan memberikan komentar terhadap hasil pengamatannya dengan menggunakan ide dan kata-kata mereka sendiri. Ini merupakan penerapan dari ilmu psikologi yang dikemukakan oleh vygostysky yang menyatakan bahwa diskusi kelompok dan situasi pembelajaran kooperatif memberikan kesempatan bagi siswa untuk

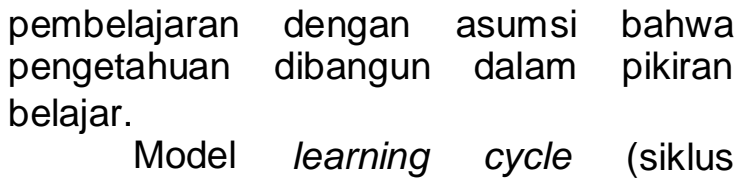


mengekspresikan pemahamannya dan menerima umpan balik dari orang lain. Fase penjelasan bisa singkat karena fase berikutnya akan ada waktu untuk merestruktur lagi dan memperluas pengenalan ini terhadap konsep, proses dan keterampilan. Pada tahap elaboration, guru memberikan klrarifikasi atau gagasan siswa yang masih bersifat miskonsepsi dan memberikan kesempatan pada siswa untuk membuat jalinan konsep dalam struktur kognitifnya dengan cara mengaitkan atau mengembangkan konsep-konsep dan keterampilanketerampilan yang diperolehnya pada situasi yang berbeda. Siswa secara individu maupun kelompok berlatih menerapkan konsep yang telah mereka peroleh sebelumnya untuk menganalisis konsep baru yang berhubungan dengan tahap sebelumnya. Sedangkan pada tahap evaluation siswa dimungkinkan mengevaluasi tahapan yang telah dilaksanakan dan dapat melakukan evaluasi diri. Penerapan model learning cycle (siklus belajar) menurut (Suprijono 2016) memberikan kelebihan, yaitu sebagai berikut. Pertama meningkatkan motivasi belajar karena siswa dilibatkan secara aktif dalam proses pembelajaran, kedua membantu mengembangkan sikap ilmiah peserta didik, ketiga pembelajaran menjadi lebih bermakna. Kelebihan model learning cycle (siklus belajar) di atas sangat mendukung dalam meningkatkan keterampilan sosial siswa dalam proses pembelajaran di kelas.

Sebagai mahluk sosial, individu dituntut mampu mengatasi segala permasalahan yang timbul sebagai hasil dari interaksi dengan lingkungan sosial dan mampu menampilkan diri sesuai dengan aturan atau norma yang berlaku. Menurut Maryani (2011) mendefinisikan keterampilan sosial merupakan suatu kemampuan atau kecakapan yang tampak dalam tindakan yaitu mampu mencari, memilah dan mengolah informasi, mampu mempelajari hal-hal untuk memecahkan masalah sehari-hari memiliki keterampilan berkomunikasi baik lisan maupun tulisan, saling menghargai, mampu bekerjasama dengan orang lain, mampu mentransformasikan kemampuan akademik dan beradaptasi dengan perkembangan masyarakat global. Sedangkan menurut (Bachri 2010) keterampilan sosial adalah kemampuan individu untuk berkomunikasi efektif dengan orang lain baik secara verbal maupun non verbal sesuai dengan situasi dan kondisi yang ada pada saat itu, diman keterampilan ini merupakan perilaku yang dipelajari. Selanjutnya menurut Jarolimek (dalam Bachri 2010) aspek-aspek keterampilan sosial yang perlu dimiliki oleh siswa adalah sebagai berikut. Pertama keterampilan untuk hidup dan bekerjasama, kedua keterampilan untuk mengontrol diri dan orang lain, ketiga keterampilan berinteraksi, keempat keterampilan bertukar pikiran dan pengalaman. Keterampilan sosial juga sangat penting di dalam pembelajaran IPS.

Di dalam pembelajaran IPS siswa diharapkan mampu memiliki keterampilan sosial yang baik. Menurut Trianto (2010) IImu Pengetahuan Sosial (IPS) merupakan integrasi dari berbagai cabang ilmu-ilmu sosial, seperti sosiologi, sejarah, geografi, ekonomi, politik, hukum, dan budaya. IPS dirumuskan atas dasar realitas dan fenomena sosial yang mewujudkan suatu pendekatan interdisipliner dari aspek dan cabang-cabang ilmu-ilmu sosial (sosiologi, sejarah, geografi, ekonomi, politik, hukum, dan budaya). Sedangkan pengertian menurut Sapriya (2008) "mengemukakan bahwa salah satu karakteristik sosial studies adalah bersifat dinamis, artinya selalu berubah sesuai dengan tingkat perkembangan masyarakat". Tujuan dari Ilmu Pengetahuan Sosial adalah sebagai berikut. Pertama untuk memahami dan mengembangkan pengetahuan, nilai, sikap, keterampilan sosial, kewarganegaraan, fakta, peristiwa, konsep, dan generalisasi, serta mampu mereflesikan dalam kehidupan masyarakat, bangsa, dan Negara. Kedua Untuk mengembangkan potensi peserta didik agar peka terhadap masalah sosial yang terjadi dimasyarakat. Ketiga Memiliki sikap mental positif terhadap perbaikan segala ketimpangan yang terjadi. Keempat Terampil mengatasi setiap masalah yang terjadi sehari-hari baik yang menimpa 
dirinya sendiri maupun menimpa masyarakat.

Pada saat melakukan observasi awal di SMP Negeri 2 Seririt yang menunjukkan bahwa masih rendahnya keterampilan sosial yang dimiliki oleh masing-masing siswa dilihat pada saat melaksanakan tugas kerja kelompok di dalam kelas, siswa belum mampu mengembangkan keterampilan sosial secara maksimal, hal ini terlihat dari belum adanya kerjasama yang baik antar siswa dalam menyelesaikan tugas kelompok, semangat belajar siswa rendah dan keaktifan siswa rendah, siswa hanya berusaha menghafal materi yang telah diberikan oleh guru selama pembelajaran di kelas, pembelajaran yang dilakukan oleh guru belum mampu menumbuhkan dan membangun kemampuan untuk bekerjasama, memecahkan, dan menyikapi masalah sosial yang ada di lingkungan sekitar, karena pembelajaran yang dilakukan oleh guru masih pada pencapaian ketuntasan materi tanpa diimbangi dengan pencapaian keterampilan sosial. Memperhatikan kelebihan penerapan model learning cycle (siklus belajar) di atas maka penerapan model ini sangat cocok untuk mengatasi permasalahan rendahnya keterampilan sosial siswa di dalam kelas. Berdasarkan uraian di atas, maka penulis tertarik untuk melakukan penelitian dengan judul "Pengaruh Penerapan Model Pembelajaran Learning Cycle (Siklus Belajar) 5 Fase Terhadap Keterampilan Sosial Siswa Pada Mata Pelajaran IPS Kelas VII SMP Negeri 2 Seririt"

\section{METODE}

Penelitian ini merupakan penelitian eksperimen semu (quasi experiment) terhadap siswa dalam suatu kelas. Rancangan eksperimen yang digunakan adalah rancangan atau desain kelompok kontrol hanya pos tes saja (Posttes-Only Control Group Design). Kelompok eksperimen dikenai perlakuan pembelajaran dengan model pembelajaran learning cycle (siklus belajar) 5 (lima) Fase dan kelomok kontrol dikenai model pembelajaran konvensional dalam jangka waktu tertentu, dan kedua kelompok dikenai pengukuran yang sama. Penelitian ini dilaksanakan di SMP Negeri 2 Seririt yang beralamat di Jalan Raya Pangkung Paruk - Banjar Asem, Kecamatan Seririt, Kabupaten Buleleng.

Jenis data yang diperoleh dari hasil penelitian ini adalah data kuantitatif. Data kuantitatif adalah data yang berbentuk angka. Data kuantitatif dalam penelitian ini adalah data berupa skor keterampilan sosial siswa pada mata pelajaran IPS. Sumber data yang digunakan adalah data primer dan data sekunder. Data primer yaitu data yang diperoleh secara langsung yang berupa data hasil observasi. Data primer dalam penelitian ini berupa keterampilan sosial siswa dan data sekunder yaitu data yang diperoleh dari tata usaha berupa nama siswa kelas VII SMP Negeri 2 Seririt.

Subjek dalam penelitian ini adalah siswa kelas VII C yang berjumlah 32 orang sebagai kelas eksperimen dan siswa kelas VII D yang berjumlah 31 orang sebagai kelas kontrol. Objek dalam penelitian ini adalah keterampilan sosial siswa dan model pembelajaran learning cycle (siklus belajar) 5 (lima) fase.

Penelitian ini melibatkan variabel bebas dan variabel terikat yang dijelaskan sebagai berikut. Variabel bebas dalam penelitian ini adalah pembelajaran menggunakan model learning cycle (siklus belajar) 5 (lima) fase dan Variabel terikat dalam penelitian ini adalah keterampilan sosial siswa.

Definisi operasional variabel dalam penelitian ini yang pertama Model Pembelajaran Learning Cycle (Siklus Belajar) 5 (lima) Fase Model pembelajaran learning cycle adalah model pembelajaran yang berpusat pada pebelajar (student centered). Model pembelajaran learning cycle terdiri dari fase-fase atau tahaptahap kegiatan yang diorganisasikan sedemikian rupa sehingga siswa dapat menguasai kompetensi-kompetensi yang harus dicapai dalam pembelajaran dengan jalan berperan aktif. Kedua Keterampilan sosial adalah kemampuan atau kecakapan untuk hidup bermasyarakat atau keterampilan sosial dapat diartikan sebagai keterampilan yang harus dimiliki oleh siswa untuk mengatasi 
permasalahannya sebagai akibat interaksi dengan lingkungannya.

Metode pengumpulan data yang digunakan dalam penelitian ini yaitu sebagai berikut. Teknik observasi menggunakan lembaran pengamatan siswa untuk mengamati keterampilan sosial siswa yang diharapkan muncul dalam pembelajaran IPS dengan model pembelajaran learning cycle (siklus belajar) 5 fase yang dilakukan setiap kali tatap muka. Observasi dilakukan untuk mengamati kegiatan yang dilakukan oleh guru dan siswa dalam proses belajar mengajar. Dokumentasi, metode ini digunakan untuk mengumpulkan data berupa foto proses belajar mengajar di dalam kelas VII C yang berjumlah 32 orang sebagai kelas eksperimen dan VII D yang berjumlah 31 orang sebagai kelas kontrol. Instrumen dalam penelitian ini adalah berupa lembar pengamatan keterampilan sosial siswa. Lembar pengamatan keterampilan sosial siswa digunakan untuk memperoleh data tentang keterampilan sosial siswa dan akan dilakukan pengamatan pada kedua kelompok.

Pengujian hipotesis yang digunakan dalam penelitian ini adalah uji-t yang menggunakan output spss. sebelum dilakukan pengujian hipotesis untuk mendapatkan simpulan, maka prasyarat yang harus dipenuhi adalah melakukan uji asumsi. Uji asumsi klasik yang dilakukan adalah uji asumsi normalitas dan homogenitas, setelah data dikatakan berdistribusi normal dan homogen, data memiliki varian yang sama maka uji hipotesis bisa dilakukan dengan menggunakan uji-t.

\section{HASIL DAN PEMBAHASAN Hasil Penelitian}

Berdasarkan data hasil penelitian mengenai model pembelajaran learning cycle (siklus belajar) 5 fase terhadap keterampilan sosial siswa pada siswa kelas VII diperoleh peneliti melalui lembar observasi terhadap 63 responden. Adapun rincian mengenai hasil penelitian terkait dengan model pembelajaran learning cycle (siklus belajar) 5 fase terhadap keterampilan sosial siswa pada mata pelajaran IPS siswa kelas VII SMP Negeri 2 Seririt ditinjau dari masing-masing indikator dapat dilihat pada tabel 1, 2, 3 dan 4 berikut ini.

Berdasarkan hasil analis data menunjukkan bahwa pengaruh keterampilan sosial siswa yang menggunakan pembelajaran model learning cycle (siklus belajar) 5 fase dan pembelajaran model konvensional dilihat dari indikator keterampilan untuk hidup dan bekerjasama dapat diketahui dengan menggunakan uji-t pada output spss. Data keterampilan sosial siswa untuk hidup dan bekerjasama dapat dilihat pada tabel 1 dibawah ini yaitu sebagai berikut.

Tabel 1. Hasil Uji-t Keterampilan Keterampilan Untuk Hidup dan Bekeriasama Independent Samples Test

\begin{tabular}{|c|c|c|c|c|c|c|c|c|c|}
\hline \multicolumn{10}{|c|}{ Independent Samples Test } \\
\hline & \multicolumn{4}{|c|}{$\begin{array}{l}\text { Levene's Test } \\
\text { for Equality of } \\
\text { Variances }\end{array}$} & \multicolumn{5}{|c|}{ t-test for Equality of Means } \\
\hline & \multirow[b]{2}{*}{$\mathrm{F}$} & \multirow[b]{2}{*}{ Sig. } & \multirow[b]{2}{*}{$\mathrm{T}$} & \multirow[b]{2}{*}{ Df } & \multirow{2}{*}{\multicolumn{2}{|c|}{$\begin{array}{lc} & \text { Mean } \\
\text { Sig. (2- } & \text { Differen } \\
\text { tailed) } & \text { ce }\end{array}$}} & \multirow[b]{2}{*}{$\begin{array}{l}\text { Std. Error } \\
\text { Difference }\end{array}$} & \multicolumn{2}{|c|}{$\begin{array}{l}95 \% \text { Confidence } \\
\text { Interval of the } \\
\text { Difference }\end{array}$} \\
\hline & & & & & & & & Lower & Upper \\
\hline $\begin{array}{l}\text { Ketera Equal } \\
\text { mpilan variances } \\
\text { untuk assumed }\end{array}$ & .052 & .820 & 5.272 & 61 & .000 & 2.44689 & .46416 & 1.51875 & 3.37502 \\
\hline $\begin{array}{l}\text { hidup Equal } \\
\text { dan } \\
\text { bekerj variances } \\
\text { asama not assumed }\end{array}$ & & & 5.274 & 60.993 & .000 & 2.44689 & .46399 & 1.51907 & 3.37470 \\
\hline
\end{tabular}

Sumber: Output SPSS16.0 for Window 
Berdasarkan tabel 1 di atas, diperoleh nilai $t$ sebesar 5,272 dengan nilai signifikan $0,000<0,05$ sehingga $\mathrm{H}_{0}$ ditolak dan $\mathrm{H}_{\mathrm{a}}$ diterima. Jadi dapat disimpulkan bahwa terdapat pengaruh yang positif keterampilan sosial siswa yang menggunakan pembelajaran model learning cycle (siklus belajar) 5 fase dan pembelajaran model konvensional dilihat dari keterampilan untuk hidup dan bekerjasama.

Berdasarkan hasil analis data menunjukkan bahwa pengaruh keterampilan sosial siswa yang menggunakan pembelajaran model learning cycle (siklus belajar) 5 fase dan pembelajaran model konvensional dilihat dari keterampilan untuk mengontrol diri dan orang lain dapat diketahui dengan menggunakan uji-t yang pada output spss. Data keterampilan sosial siswa untuk mengontrol diri dan orang lain dapat dilihat pada tabel 2 yaitu sebagai berikut.

Berdasarkan tabel 2 di bawah ini, diperoleh nilai $t$ sebesar 5,873 dengan nilai signifikan $0,003<0,05$ sehingga $\mathrm{H}_{0}$ ditolak dan $\mathrm{H}_{\mathrm{a}}$ diterima. Jadi dapat disimpulkan bahwa terdapat pengaruh yang positif keterampilan sosial siswa yang menggunakan pembelajaran model learning cycle (siklus belajar) 5 fase dan pembelajaran model konvensional dilihat dari keterampilan untuk mengontrol diri dan orang lain yaitu sebagai berikut.

Tabel 2. Hasil Uji-t Keterampilan Untuk Mengontrol Diri dan Orang Lain

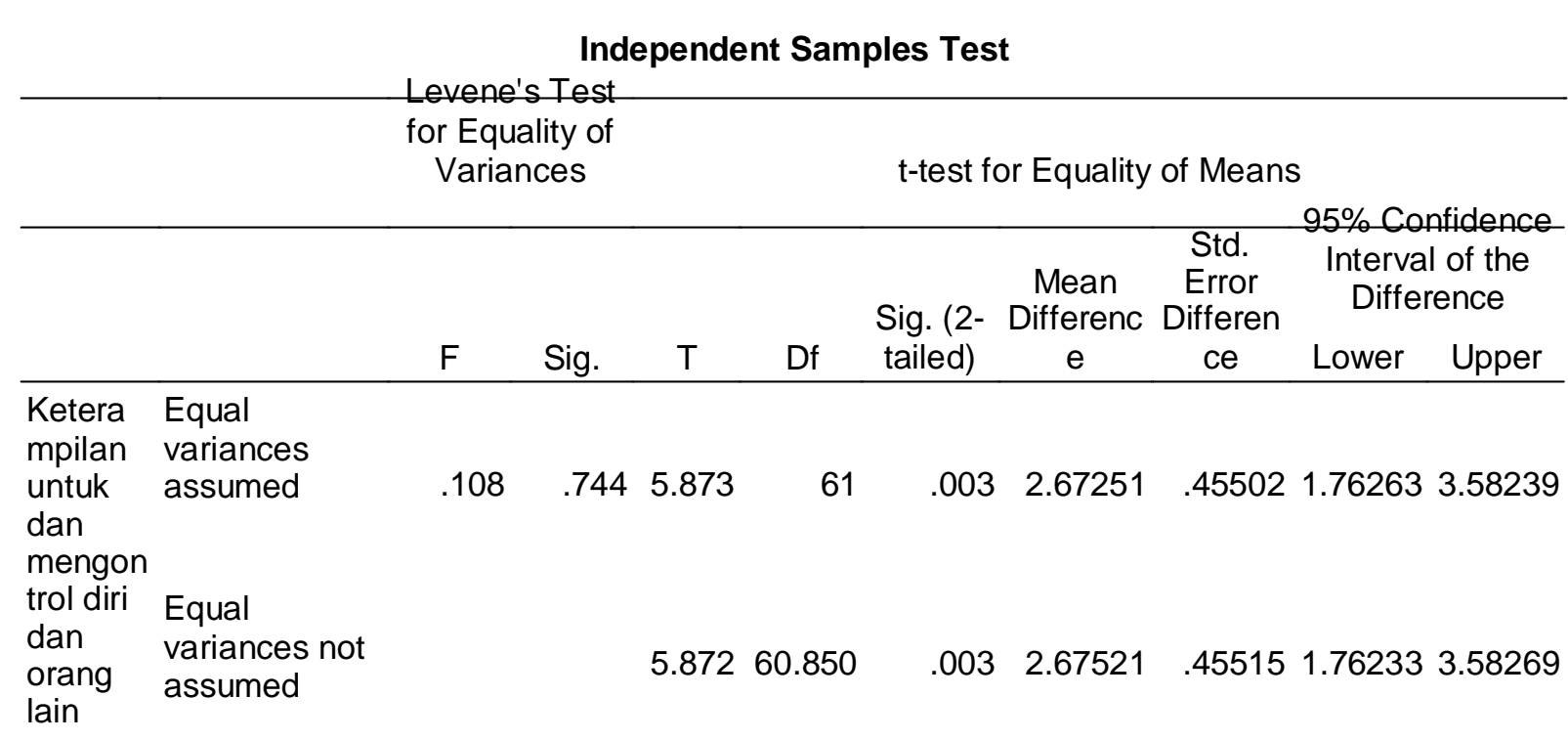

\section{Sumber : Output SPSS16.0 for Window}

Berdasarkan tabel 3 yang tertera di bawah ini data tersebut menunjukkan bahwa pengaruh keterampilan sosial siswa yang menggunakan pembelajaran model learning cycle (siklus belajar) 5 fase dan pembelajaran model konvensional dilihat dari indikator keterampilan sosial pada bagian pertama yaitu keterampilan berinteraksi dapat diketahui dengan menggunakan uji-t yang menggunakan output spss. Data keterampilan sosial siswa pada keterampilan sosial indikator keterampilan berinteraksi dapat dilihat pada tabel 3 yaitu sebagai berikut.
Kemudian, berdasarkan hasil analisis data pada tabel 3 yang tertera di bawah ini, menyatakan bahwa diperoleh nilai $\mathrm{t}$ sebesar 5,058 dengan nilai signifikan $0,005<0,05$ sehingga $\mathrm{H}_{0}$ ditolak dan $\mathrm{H}_{\mathrm{a}}$ diterima. Jadi dapat disimpulkan bahwa terdapat pengaruh keterampilan sosial siswa yang menggunakan pembelajaran model learning cycle (siklus belajar) 5 fase dan pembelajaran model konvensional dapat dilihat dari indikator keterampilan sosial pada bagian ketiga yaitu keterampilan berinteraksi sebagai berikut di bawah ini. 
Tabel 3. Hasil Uji-t Keterampilan Berinteraksi

\begin{tabular}{|c|c|c|c|c|c|c|c|c|}
\hline \multicolumn{9}{|c|}{ Independent Samples Test } \\
\hline & \multicolumn{4}{|c|}{$\begin{array}{l}\text { Levene's Test } \\
\text { for Equality of } \\
\text { Variances }\end{array}$} & \multicolumn{4}{|c|}{ t-test for Equality of Means } \\
\hline & $\mathrm{F}$ & Sig. & $\mathrm{T}$ & Df & $\begin{array}{lc} & \text { Mean } \\
\text { Sig. (2- Differen } \\
\text { tailed) ce }\end{array}$ & $\begin{array}{l}\text { Std. } \\
\text { Error } \\
\text { Differe } \\
\text { nce }\end{array}$ & $\begin{array}{r}95 \% \text { C } \\
\text { Intern } \\
\text { Diff } \\
\text { Lower }\end{array}$ & $\begin{array}{l}\text { nfidence } \\
\text { al of the } \\
\text { rence } \\
\text { Jpp } \\
\text { er }\end{array}$ \\
\hline \multirow{2}{*}{$\begin{array}{l}\text { Ketera Equal } \\
\text { mpilan variance } \\
\text { berinte assume } \\
\text { raksi } \quad \text { Equal } \\
\begin{aligned} & \text { variance } \\
& \text { not assu }\end{aligned}\end{array}$} & .243 & .139 & 5.058 & 61 & .0052 .15521 & .42611 & 1.30316 & 3.00726 \\
\hline & & & 5.044 & 58.627 & .0052 .15521 & .42727 & 1.30013 & 3.01030 \\
\hline
\end{tabular}

Sumber : Output SPSS16.0 for Windows

Berdasarkan hasil analis data menunjukkan bahwa pengaruh keterampilan sosial siswa yang menggunakan pembelajaran model learning cycle (siklus belajar) 5 fase dan pembelajaran model konvensional dilihat dari keterampilan bertukar pikiran dan pengalaman dapat diketahui dengan menggunakan uji-t. Data keterampilan sosial siswa bertukar pikiran dan pengalaman dapat dilihat pada tabel 4 yaitu sebagai berikut.

Tabel 4. Hasil Uji-t Keterampilan Bertukar Pikiran dan Pengalaman

\section{Independent Samples Test}

\section{Levene's Test \\ for Equality of Variances}

t-test for Equality of Means

\begin{tabular}{|c|c|c|c|c|c|c|c|c|c|c|}
\hline & & $\mathrm{F}$ & Sig. & $\mathrm{T}$ & Df & $\begin{array}{l}\text { Sig. (2- } \\
\text { tailed) }\end{array}$ & $\begin{array}{c}\text { Mean } \\
\text { Differen } \\
\text { ce }\end{array}$ & $\begin{array}{l}\text { Std. } \\
\text { Error } \\
\text { Differen } \\
\text { ce }\end{array}$ & $\begin{array}{r}95 \% \text { C } \\
\text { Interv } \\
\text { Diff } \\
\text { Lower }\end{array}$ & $\begin{array}{l}\text { onfidence } \\
\text { /al of the } \\
\text { erence } \\
\text { Upp } \\
\text { er }\end{array}$ \\
\hline \multirow{2}{*}{$\begin{array}{l}\text { Ketera } \\
\text { mpilan } \\
\text { bertukar } \\
\text { pikiran } \\
\text { dan } \\
\text { pengala } \\
\text { man }\end{array}$} & $\begin{array}{l}\text { Equal } \\
\text { variances } \\
\text { assumed }\end{array}$ & .036 & .050 & 6.268 & 61 & .000 & 2.66564 & .4228 & 1.81523 & 3.51604 \\
\hline & $\begin{array}{l}\text { Equal } \\
\text { variances not } \\
\text { assumed }\end{array}$ & & & 6.273 & 60.983 & .000 & 2.66564 & .42495 & 1.81589 & 3.51538 \\
\hline
\end{tabular}

Sumber : Output SPSS16.0 for Window

Berdasarkan tabel 4 di atas, diperoleh nilai $t$ sebesar 6,268 dengan nilai signifikan $0,000<0,05$ sehingga $\mathrm{H}_{0}$ ditolak dan $\mathrm{H}_{\mathrm{a}}$ diterima. Jadi dapat disimpulkan bahwa terdapat pengaruh yang positif keterampilan sosial siswa yang menggunakan pembelajaran model learning cycle (siklus belajar) 5 fase dan pembelajaran model konvensional dilihat dari keterampilan bertukar pikiran dan pengalaman.

\section{Pembahasan}

Berdasarkan hasil penelitian di kelas VII SMP Negeri 2 Seririt menunjukkan bahwa, pertama terdapat pengaruh keterampilan sosial siswa yang menggunakan pembelajaran model 
learning cycle (siklus belajar) 5 fase dan pembelajaran model konvensional dilihat dari keterampilan untuk hidup dan bekerjasama, pada nilai t sebesar 5,272 dengan nilai signifikan $0,000<0,05$ sehingga $\mathrm{H}_{0}$ ditolak dan $\mathrm{H}_{\mathrm{a}}$ diterima. Kedua terdapat pengaruh keterampilan sosial siswa yang menggunakan pembelajaran model learning cycle (siklus belajar) 5 fase dan pembelajaran model konvensional dilihat dari keterampilan untuk mengontrol diri dan orang lain, pada nilai $t$ sebesar 5,873 dengan nilai signifikan $0,003<0,05$ sehingga $\mathrm{H}_{0}$ ditolak dan $\mathrm{H}_{\mathrm{a}}$ diterima. Ketiga terdapat pengaruh keterampilan sosial siswa yang menggunakan pembelajaran model learning cycle (siklus belajar) 5 fase dan pembelajaran model konvensional dilihat dari keterampilan berinteraksi, pada nilai $t$ sebesar 5,058 dengan nilai signifikan $0,005<0,05$ sehingga $\mathrm{H}_{0}$ ditolak dan $\mathrm{H}_{\mathrm{a}}$ diterima. Keempat terdapat pengaruh keterampilan sosial siswa yang menggunakan pembelajaran model learning cycle (siklus belajar) 5 fase dan pembelajaran model konvensional dilihat dari keterampilan bertukar pikiran dan pengalaman, pada nilai t sebesar 6,268 dengan nilai signifikan $0,000<0,05$ sehingga $\mathrm{H}_{0}$ ditolak dan $\mathrm{H}_{\mathrm{a}}$ diterima.

Hal ini sejalan dengan pendapat Trianto (2010), menurut teori kontruktivis bahwa siswa harus menemukan sendiri dan menstransformasikan informasi kompleks, mengecek informasi baru dengan aturan-aturan lama dan merevisinya apabila aturan-aturan itu tidak lagi sesuai. Peran guru dalam proses pembelajaran berlangsung yaitu dengan memberikan penguatan. Penguatan tersebut dapat berupa pemberian tugas yang disenangi oleh siswa dalam bentuk kegiatan pembelajaran yang menyenangkan dengan tujuan agar siswa dapat lebih giat berpartisipasi dalam interaksi belajar mengajar. Menurut Suprijono (2016) model pembelajaran learning cycle (siklus belajar) 5 fase model pembelajaran yang terdiri dari fase-fase atau tahap-tahap kegiatan yang diorganisasikan sedemikian rupa sehingga siswa dapat menguasai kompetensikompetensi yang harus dicapai dalam pembelajaran dengan jalan berperan aktif. Dari pendapat di atas dalam kegiatan pembelajaran yang dilakukan pada kelompok eksperimen dengan menerapkan model pembelajaran learning cycle (siklus belajar) 5 fase yaitu model ini menekankan kepada aktivitas siswa untuk menemukan konsep yang telah dipelajari melalui kegiatan diskusi kelompok dan mampu mengatasi permasalahan yang terjadi diantaranya yaitu sebagai berikut. Pertama dengan adanya diskusi kelompok siswa mampu saling bertukar pikiran satu sama lain dan informasi tentang suatu topik permasalahan sesuai dengan pengetahuan awal yang dimiliki siswa. Kedua siswa mampu mengembangkan keterampilan sosial, dilihat dari kerjasama yang baik antar siswa dalam menyelesaikan tugas kelompok. Ketiga siswa mampu berinteraksi dan mengembangkan sikap demokratis, terlihat saat siswa berpartisipasi aktif dalam kelompok dan mampu meyakinkan orang lain. Keempat siswa mampu menghargai pendapat orang lain, terlihat pada saat kelompok lain melaksanakan persentasi di depan kelas sedangkan kelompok yang lainnya mampu memberikan tanggapan atau sanggahan yang bersifat positif terhadap kelompok yang persentasi. Hal ini sejalan dengan pendapat Jarolimek (dalam Bachri, 2010) aspek-aspek yang perlu dimiliki oleh siswa adalah keterampilan untuk hidup dan bekerjasama, keterampilan untuk mengontrol diri dan orang lain, keterampilan berinteraksi, keterampilan bertukar pikiran dan pengalaman. Selain itu hal ini sesuai dengan pendapat (Wena 2009) sintaks model pembelajaran learning cycle (siklus belajar) 5 fase pada tahap Exploration (eksplorasi) yaitu pada tahap ini, siswa diberi kesempatan untuk bekerjasama dalam kelompok kecil, berdiskusi, dan siswa mampu memecahkan permasalahan yang diberikan oleh guru sehingga kegiatan pembelajaran berlangsung dengan baik. Pada tahap Explaination (penjelasan) yaitu siswa diberikan kesempatan untuk mengekspresikan pemahamannya dan menerima umpan balik dari orang lain. Pada tahap Elaboration (penerapan 
konsep) pada tahap ini siswa mampu memperoleh keterampilan baru dari informasi yang diterima sehingga pembelajaran menjadi lebih bermakna.

Tujuan dari model pembelajaran learning cycle (siklus belajar) 5 fase yaitu sebagai berikut. Pertama meningkatkan motivasi belajar karena peserta didik dilibatkan secara aktif dalam proses pembelajaran. Kedua pembelajaran menjadi lebih bermakna. Ketiga siswa dalam setiap anggota kelompok bertanggung jawab atas segala sesuatu yang dikerjakan dalam kelompoknya, mempunyai tujuan yang sama, membagi tugas dan tanggung jawab yang sama diantara anggota kelompoknya. Keempat berbagi kepemimpinan dan membutuhkan keterampilan untuk belajar bersama selama proses pembelajaran berlangsung.

Hal ini didukung dengan hasil penelitian yang dilakukan oleh Amri (2017) dalam penelitiannya yang berjudul Pengaruh Model Pembelajaran Learning Cycle Terhadap Motivasi Belajar Biologi Pada Siswa Kelas XI IPA Pokok Bahasan Sel SMA Negeri 2 Parepare . Berdasarkan hasil analisis uji-t pada penelitian tersebut diperoleh thitung 7,80 dan $t_{\text {tabel }} 2,000$ (thitung $7,80>t_{\text {tabel }} 2,000$ ) atau nilai signifikansi sebesar $0,000<0,05$, sehingga dapat disimpulkan bahwa $\mathrm{H}_{0}$ ditolak dan $\mathrm{H}_{1}$ diterima. Berarti dapat disimpulkan bahwa model pembelajaran learning cycle berpengaruh terhadap motivasi belajar biologi.

Sedangkan penelitian Wijeyanti (2014) dalam penelitiannya yang berjudul "Pengaruh Model Pembelajaran Learning Cycle 5E Berbantuan Peta Konsep (Concept Mapping) Terhadap Hasil Belajar IPA Siswa Kelas V SD Negeri 2 Tibubeneng Badung". Berdasarkan hasil analisis uji-t pada penelitian tersebut diperoleh nilai signifikansi sebesar 0,000 < 0,05, sehingga dapat disimpulkan bahwa $\mathrm{H}_{0}$ ditolak dan $\mathrm{H}_{1}$ diterima. Berarti dapat disimpulkan bahwa terdapat perbedaan yang signifikan hasil belajar IPA antara kelompok siswa yang diajar dengan model pembelajaran learning cycle 5E berbantuan peta konsep (concept mapping) dengan kelompok siswa yang diajar dengan menggunakan model pembelajaran konvensional di kelas V SD Negeri 2 Tibubeneng Badung.

Dari uraian di atas, menunjukkan bahwa ada pengaruh model pembelajaran learning cycle (siklus belajar) 5 fase terhadap keterampilan sosial siswa. Oleh karena itu terdapat perbedaan keterampilan sosial siswa yang diajar dengan menggunakan model pembelajaran learning cycle (siklus belajar) 5 fase dengan siswa yang diajar dengan menggunakan model pembelajaran konvensional.

\section{SIMPULAN DAN SARAN Simpulan}

Berdasarkan hasil penelitian dan pembahasan, dapat disimpulkan yaitu sebagai berikut. Pertama terdapat pengaruh yang positif keterampilan sosial siswa yang menggunakan pembelajaran model learning cycle (siklus belajar) 5 fase dan pembelajaran model konvensional dilihat dari indikator yang pertama keterampilan untuk hidup dan bekerjasama pada nilai $t$ sebesar 5,272 dengan nilai signifikan $0,000<0,05$ sehingga $\mathrm{H}_{0}$ ditolak dan $\mathrm{H}_{a}$ diterima. Kedua terdapat pengaruh yang positif keterampilan sosial siswa yang menggunakan pembelajaran model learning cycle (siklus belajar) 5 fase dan pembelajaran model konvensional dilihat dari indikator yang kedua keterampilan untuk mengontrol diri dan orang lain pada nilai $t$ sebesar 5,873 dengan nilai signifikan 0,003 $<0,05$ sehingga $\mathrm{H}_{0}$ ditolak dan $\mathrm{H}_{\mathrm{a}}$ diterima. Ketiga terdapat pengaruh yang positif keterampilan sosial siswa yang menggunakan pembelajaran model learning cycle (siklus belajar) 5 fase dan pembelajaran model konvensional dilihat dari indikator yang ketiga keterampilan berinteraksi pada nilai $\mathrm{t}$ sebesar 5,058 dengan nilai signifikan 0,005 $<0,05$ sehingga $\mathrm{H}_{0}$ ditolak dan $\mathrm{H}_{\mathrm{a}}$ diterima. Keempat terdapat pengaruh yang positif keterampilan sosial siswa yang menggunakan pembelajaran model learning cycle (siklus belajar) 5 fase dan pembelajaran model konvensional dilihat dari indikator yang keempat keterampilan bertukar pikiran dan pengalaman pada nilai $t$ sebesar 6,268 dengan nilai 
signifikan $0,000<0,05$ sehingga $\mathrm{H}_{0}$ ditolak dan $\mathrm{H}_{\mathrm{a}}$ diterima.

\section{Saran}

Berdasarkan temuan-temuan dalam penelitian ini, dapat disampaikan saransaran yaitu sebagai berikut. Pertama kepada guru disarankan untuk dapat menerapkan model pembelajaran learning cycle (siklus belajar) 5 fase dalam proses pembelajaran dengan cara memaksimalkan tahapan-tahapan atau fase-fase kegiatan yang meliputi tahap Engagement (pembangkitan minat), Exploration (eksplorasi), Explanation (penjelasan), Elaboration (penerapan konsep), Evaluation (evaluasi), sehingga siswa menjadi lebih aktif, termotivasi dan interaksi siswa dapat berlangsung dengan baik. Kedua kepada sekolah disarankan agar dapat meningkatkan fasilitas sebagai pendukung sumber belajar guru dalam meningkatkan kualitas pembelajaran yang menyenangkan di sekolah sehingga sekolah mampu menghasilkan siswa yang berkualitas. Ketiga kepada siswa hendaknya lebih membiasakan diri untuk lebih aktif, mampu berpartisipasi, berinteraksi dalam pembelajaran, tidak selalu menunggu arahan dari guru untuk mempelajarai suatu konsep. Siswa dapat belajar dengan teman ataupun mencari sumber belajar sebanyak-banyaknya sehingga mampu mengkonstruksi pengetahuan sendiri khususnya dalam pembelajran IPS. Keempat kepada calon peneliti yang berminat untuk meneliti lebih lanjut dengan menggunakan model pembelajaran learning cycle (siklus belajar) 5 fase menggunakan pokok bahasan yang berbeda sehingga untuk mengetahui efektifitas penerapan model pembelajaran learning cycle (siklus belajar) 5 fase dan memperhatikan kendala yang dihadapi peneliti sebagai bahan pertimbangan untuk perbaikan dan penyempurnaan pelaksanaan penelitian berikutnya.

\section{DAFTAR PUSTAKA}

Amri \& Nursida 2017. Pengaruh Model Pembelajaran Learning Cycle Terhadap Motivasi Biologi Pada Siswa Kelas XI IPA Pokok Bahasan
Sel SMA Negeri 2 Pare-Pare." Biotek 5.

Bachri, Syamsul. 2010. Psikologi Pendidikan Berbasis Analisis Empiris Aplikatif. Jakarta: KENCANA.

Maryani, Enok. 2011. Pengembangan Program Pembelajaran IPS Untuk Peningkatan Keterampilan Sosial. Bandung: Alfabeta.

Sadia, I. Wayan. 2014. Model-Model Pembelajaran Sains Kontruktivistik. Yogyakarta: Graha IImu.

Sapriya. 2008. Pendidikan IPS. Bandung: Yasindo Multi.

Sobandi, Bandi. 2008. Model Pembelajaran Kritik Dan Apresiasi Seni Rupa. Solo: Maulana Offset.

Suastra, I. Wayan. 2017. Pembelajaran Sains Terkini. Singaraja: Undiksha.

Suprijono, Agus. 2016. Model-Model Pembelajaran Emansipatoris. Yogyakarta: Pustaka Belajar.

Trianto. 2010. Model Pembelajaran Terpadu. Jakarta: PT Bumi Aksara.

Wena, Made. 2009. Strategi Pembelajaran Inovatif Kontenporer. Jakarta: Bumi Aksara.

Wijeyanti, Irma. 2014. Pengaruh Model Pembelajaran (Learning Cycle) 5E Berbantuan Peta Konsep (Concept Mapping) Terhadap Hasil Belajar IPS Siswa Kelas $V$ SD Negeri 2 Tibubeneng Badung. universitas Pendidikan Ganesha. 